\title{
Fetal Lamb Lung Lavage and its Effect on Lung Phosphatidylcholine
}

\author{
GARY SHELDON, JANE BRAZY, BETTY TUGGLE, CARLYLE CRENSHAW, JR., \\ AND GEORGE BRUMLEY \\ Division of Perinatal Medicine, Department of Obstetrics-Gynecology and Pediatrics, Duke University Medical Center, \\ Durham, North Carolina, USA
}

\section{Summary}

The lungs of intrauterine 135-136-day-old lambs were lavaged with amnionic fluid, with or without meconium, to determine the effect on lung phosphatidylcholine (PC) concentration, synthesis, and function. No differences were apparent between animals lavaged with amnionic fluid or amnionic fluid with meconium. When lavaged lungs were compared to nonlavaged controls, no detectable differences were observed in histology or the quantity of saturated (SPC) and unsaturated phosphatidylcholine (UPC). However, the lavaged lungs retained a larger fraction of maximal lung volume at $5 \mathrm{~cm} \mathrm{H}_{2} \mathrm{O}$ distending pressure and the incorporation of $\left({ }^{32} \mathrm{P}\right)$ orthophosphate into lung $\mathrm{PC}$ was significantly reduced. In addition, two lavaged animals who became acidotic $(\mathrm{pH}$ $<7.20$ ) exhibited decreased incorporation of $\left({ }^{14} \mathrm{C}\right)$ palmitate into whole lung unsaturated, and saturated phosphatidylcholine.

\section{Speculation}

These data indicate that amnionic fluid can reduce lamb lung de novo synthesis of $\mathrm{PC}$ and may contribute to the alterations in lung PC found in neonatal syndromes of respiratory distress. Acidosis may accentuate this effect.

The fetal development of the mammalian alveolus is characterized by the transition of columnar epithelium to attenuated differentiated alveolar epithelium surrounding the fluid filled potential airspace $(8,25,35)$.

The fluid in the fetal lung, the tracheal-bronchial fluid (TBF), is comparable in volume to the functional residual volume measured after the onset of air-breathing (21). TBF flows out of the trachea at a near constant rate under uniform intrauterine conditions and is biochemically unique and distinguishable from other fetal fluids $(1,2,4,15,33)$. The rate of TBF production and the short duration of fetal respiratory activity limit the volume of TBF and amnionic fluid (AF) exchange to less than $1 \mathrm{ml}$ per ventilation under normal intrauterine conditions $(12,28,29,36)$.

Under asphyxial conditions the duration, intensity, and volume of fluid ventilation increase such that an estimated 50 ventilations will exchange approximately 0.90 of the $\operatorname{TBF}(12,21)$ with $\mathrm{AF}$. The etiologic significance of $\mathrm{AF}$ aspiration in newborn respiratory diseases has been a source of considerable discussion, but remains unresolved $(24,26,38)$. Thus, it is not evident from prior studies whether this is a direct effect of AF or meconium on the alveolar epithelium (11), the result of ischemic injury to the alveolar epithelium $(4,6,14)$, or a combination of both influences. The following report evaluates the synthesis and quantity of SPC and pressure-volume relationships of excised lungs as indices of pulmonary surfactant function in response to lung lavage in the 135day fetal lamb.

\section{MATERIALS AND METHODS}

ANIMALS

Yearling ewes with dated pregnancies $x$-rayed to confirm the pregnancy were assessed as to hemoglobin concentration, white blood count, and intestinal parasites. Healthy animals were fed horse checkers (Purina Ralston Company, St. Louis, Missouri) and ad libitum alfalfa hay and water up to $24 \mathrm{hr}$ before surgery.

The ewes at 135-136 days of gestation were anesthetized with a rapid infusion of ketamine (Vetelar, Parke Davis and Company, Detroit, Michigan), approximately $7 \mathrm{mg} / \mathrm{kg}$, and maintained with an infusion of $1 \mathrm{mg} / \mathrm{ml}$ in 0.10 dextrose and $0.25 \mathrm{~N}$ saline at a rate of 3-5 $\mathrm{ml} / \mathrm{kg} / \mathrm{min}$. A laparotomy was performed in the supine position and a hysterotomy executed over the fetal neck. The fetal neck was marsupialized to the uterine wall, the fetal trachea dissected free, ligated proximally, and cannulated $1-2 \mathrm{~cm}$ with snug fitting and bevelled tygon tubing which was secured with silk ties. The skin was closed and control animals received no further manipulations before being killed. When twins were present, one was used as a control.

\section{LAVAGE}

At the time of tracheal cannulation AF and TBF samples were inspected for the presence of meconium or blood. Thereafter, either AF obtained from amnionic sack or AF to which meconium $(4 \mathrm{~g} / 100 \mathrm{ml})$ had been added was mixed with plastic microspheres (50 microns, 3M Company, St. Paul, Minnesota). This was gently lavaged into the fetal trachea using $10 \mathrm{ml}$ volumes at a rate of eight exchanges per min. To rule out the mechanical effects of lavage, one fetal lamb was lavaged as described above with tracheal-bronchial fluid collected from another animal. After a 30-min interval, a sample of tracheal fluid was removed for comparison with the original lavage solution. Thereafter, the tracheal catheter was occluded, the lamb delivered, and an umbilical arterial blood sample obtained for acid-base and cortisol assessment before killing by exsanguination. The chest was opened immediately and the heart-lung block removed and weighed. Subsequently, the carcass and placenta were weighed.

\section{HISTOLOGY}

Small blocks of peripheral lung tissue from the left upper lobe were fixed in buffered 0.04 glutaraldehyde, embedded in epon, and 1 micron sections stained with toluidine blue for cellular detail. Thick sections were prepared also to survey for the presence of microspheres.

\section{PRESSURE-VOLUME RELATIONSHIPS}

The right lung was cannulated, distended to $40 \mathrm{~cm} \mathrm{H}_{2} \mathrm{O}$ pressure, and observed for leaks. Intact lungs were degassed under 
vacuum for $1 \mathrm{~min}$, inflated at $40 \mathrm{~cm} \mathrm{H}_{2} \mathrm{O}$ pressure until maximum volume was reached, and then deflated at $5 \mathrm{~cm} \mathrm{H}_{2} \mathrm{O}$ water decrements, and the retained volume of air recorded at each point. The deflation pressure-volume relationships were performed in triplicate and, thereafter, the lungs were weighed and the retained air volume determined by displacement.

\section{BIOCHEMICAL ANALYSIS}

Duplicate $0.5 \mathrm{~g}$ samples of the left upper lobe were incubated with $\left({ }^{14} \mathrm{C}\right)$-palmitic acid and $\left({ }^{32} \mathrm{P}\right)$-orthophosphate and the resulting phospholipids quantitated and analyzed for the incorporation of the phospholipid radioactive precursors as previously described by Brumley et al. (9). PC was further fractionated using the cryochromatographic method of Henderson and Clayton (19).
Although this method separates SPC from UPC with the PC molecule intact, due to the short half-life of $\left({ }^{32} \mathrm{P}\right)$, meaningful data concerning $\left({ }^{32} \mathrm{P}\right)$ incorporation into SPC and UPC could not be obtained when the analyses were performed. Serum cortisol determinations were performed according to the fluorometric method of Mattingly (30).

\section{REAGENTS}

All reagents were analytical grade and organic solvents were glass distilled before use.

\section{STATISTICS}

Paired $t$ tests were performed by the program described by Ostle (7).

Table 1. Comparative characteristics of control and lavaged lambs

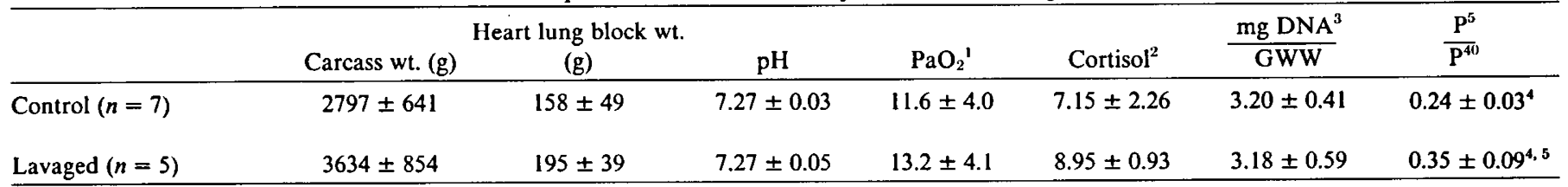

' Partial pressure of oxygen in the umbilical artery, $\mathrm{mm} \mathrm{Hg}$.

${ }^{2}$ Micrograms $\mathrm{dl}^{-1}$.

${ }^{3} \mathrm{DNA}=$ deoxyribosenucleic acid; GWW = gram wet weight.

${ }^{4} \mathrm{P}=$ volume of air in the lung at $5 \mathrm{~cm} \mathrm{H}_{2} \mathrm{O}$ distending pressure divided by the volume at $40 \mathrm{~cm} \mathrm{H}_{2} \mathrm{O}$, volume at $\mathrm{P}^{40}=1.0$.

" $P$ value $<0.05$.
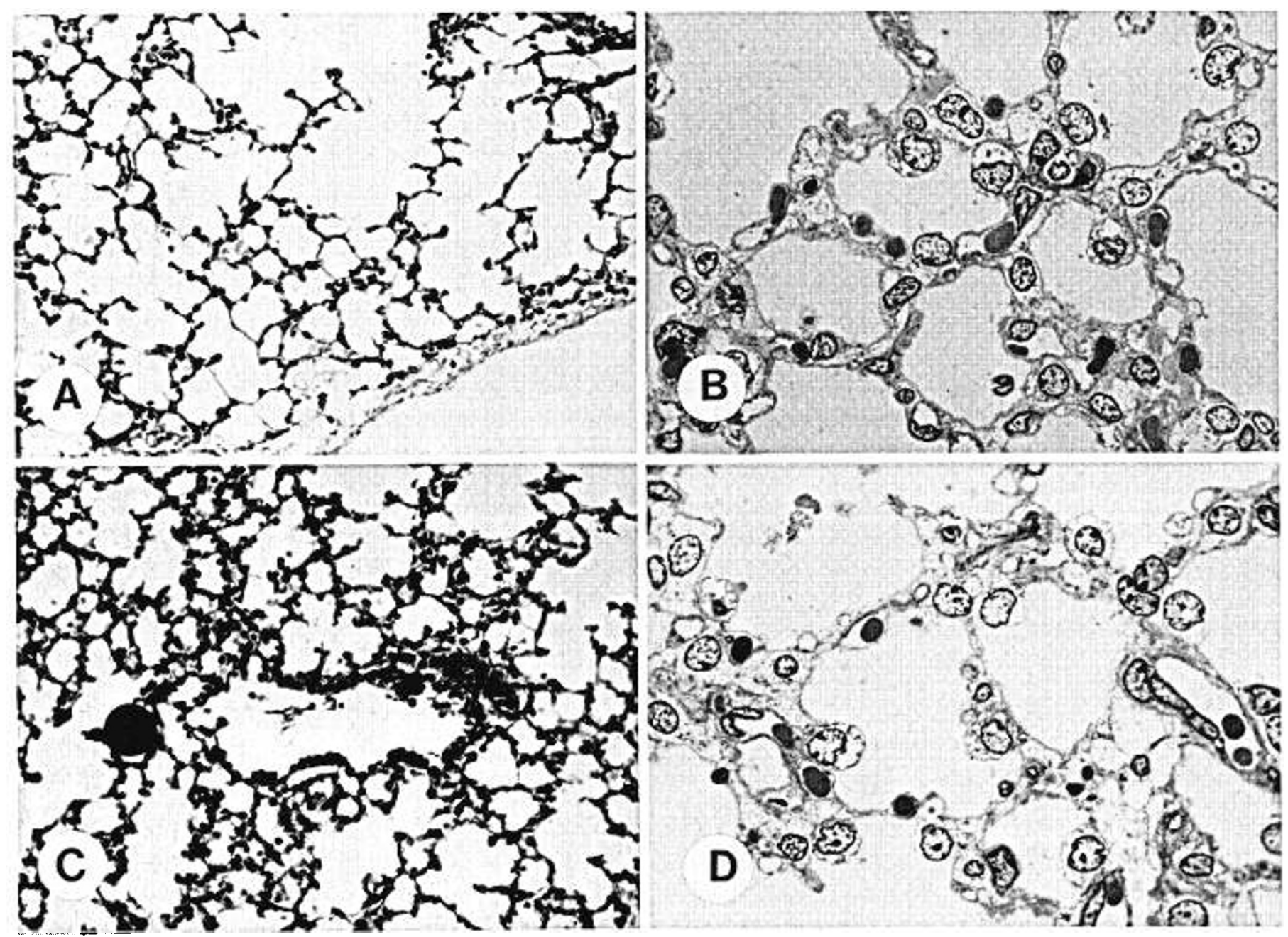

Fig. 1. 135-day fetal lamb lung from control ( $A$ and $B$ ) and lavaged (C and D) animals magnified $\times 250(A$ and $C)$ and $\times 1000$ (B and D). The histology of control and lavaged lambs is comparable with the exceptions that section $\mathrm{C}$ demonstrates a microsphere and some particulate matter from the lavage fluid in a peripheral airway. 


\section{RESULTS}

Comparative data for control and lavaged lambs at 135 days of gestation are given in Table 1 . The control group had a larger number of twins ( 5 of 7 vs. 2 of 5) however, the carcass weights and heart-lung weights were not significantly different for the two groups. Furthermore, no differences were apparent when comparisons were made regarding $\mathrm{pH}, \mathrm{PaO}_{2}$, cortisol, and lung, DNA content. However, at $5 \mathrm{~cm}$ water distending pressure, the fraction of the total lung gas volume which was retained was significantly higher in the lavaged animals $(P<0.05)$. Data concerning the acidotic animals (three control and two lavage, $\mathrm{pH}<7.20$ ) are not included in Table 1, but differed only in that they were acidotic.

Figure 1 is a composite of photomicrographs of fetal lung from control $(A \times 250$ magnification, $B \times 1000)$ and lavaged animals $(C$ $\times 250, \mathrm{D} \times 1000$ ). Photomicrograph $\mathrm{C}$ demonstrates a microsphere in a peripheral airway and debris in the alveoli characteristically observed in the lavaged animals. A comparison of photomicrographs B and D shows no evidence of gross cellular alteration in the lavaged lung.

Biochemical comparisons are presented in Figure 2 and demonstrate that the content of SPC and UPC were similar in the control, lavaged animals $(\mathrm{pH}>7.20)$, and acidotic lavaged animals $(\mathrm{pH}<7.20)$. The incorporation of $\left({ }^{32} \mathrm{P}\right)$ orthophosphate into whole lung $\mathrm{PC}$ was decreased significantly in the lavaged animals $(P<0.05)$. Similar reductions in $\left({ }^{32} \mathrm{P}\right)$ incorporation into $\mathrm{PC}(324-$ $471 \mathrm{dpm} / \mu \mathrm{g} \mathrm{PC}$ ) were observed in the two acidotic lavaged lambs. However, the incorporation of $\left({ }^{14} \mathrm{C}\right)$ palmitate into $\mathrm{PC}$ was not decreased and there was no change in the distribution of $\left({ }^{14} \mathrm{C}\right)$ palmitate between SPC and UPC in the nonacidotic lavaged lambs. Five lambs (three control and two lavaged) became acidotic $(\bar{x}) \mathrm{pH} 7.03 \pm 0.20$, range $7.14-6.68)$ during the procedure. The two acidotic lavaged lambs (LA in Fig. 2) showed reductions in $\left({ }^{14} \mathrm{C}\right)$ palmitate incorporation into whole lung PC $(742-754 \mathrm{dpm} /$ $\mu \mathrm{g} \mathrm{PC})$ and SPC (404-408 dpm/ $\mu \mathrm{g} \mathrm{SPC})$. No reduction of $\left({ }^{14} \mathrm{C}\right)$ palmitate incorporation occurred in the control (no lavage) animals which were only acidotic. No changes in SPC or UPC

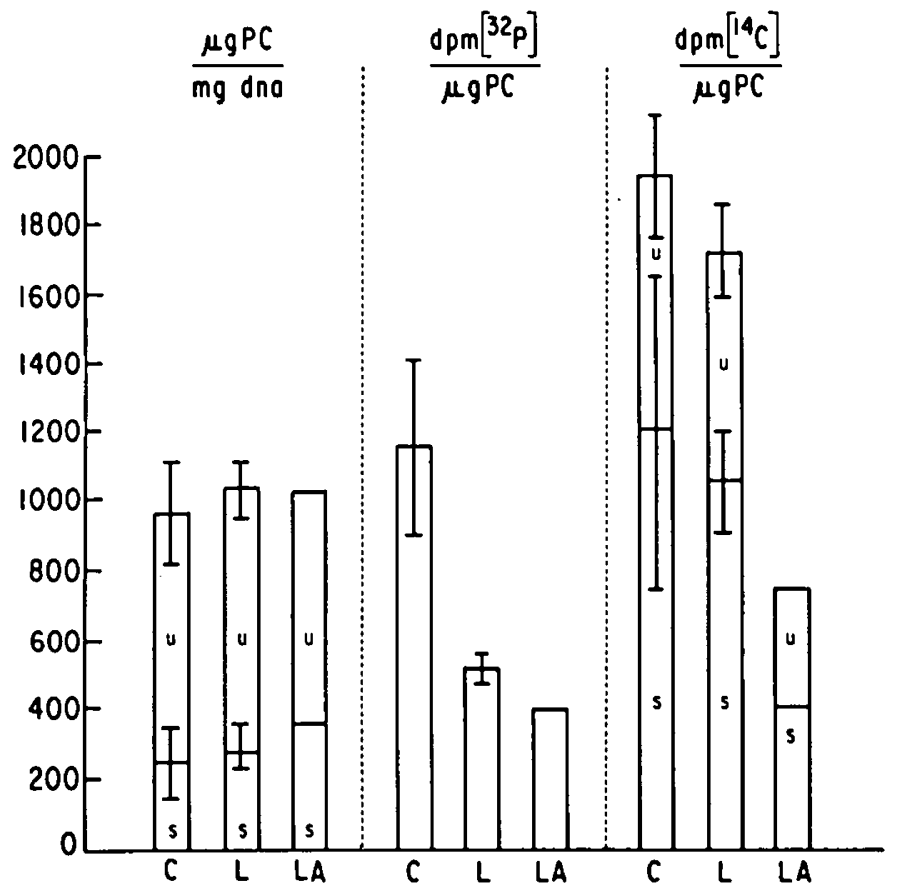

Fig. 2. Lung phosphatidylcholine concentrations and specific activities for $\left({ }^{32} \mathrm{P}\right)$ and $\left({ }^{14} \mathrm{C}\right)$ palmitate: $\mu \mathrm{g} \mathrm{PC}=$ micrograms phosphatidylcholine; $\mathrm{mg}$ DNA = milligrams deoxyribosenucleic acid; $\mathrm{dpm}=$ disintegration per minute; $\mathbf{u}=$ unsaturated phosphatidylcholine; $\mathbf{s}=$ saturated phosphatidylcholine; $C=$ control lambs; $L=$ lavaged lambs; $L A=$ lavaged-acidotic lambs; I $= \pm 1$ SD. Control $\left({ }^{32} \mathrm{P}\right) / \mu \mathrm{g}$ PC was significantly different from lavaged $\left({ }^{32} \mathrm{P}\right) / \mu \mathrm{g}$ PC, $P$ value $<0.05$. concentration or incorporation of $\left({ }^{32} \mathrm{P}\right)$ or $\left({ }^{14} \mathrm{C}\right)$ palmitate into $\mathrm{PC}$ were noted in the fetal lamb lavaged with $\mathrm{TBF}$ when compared to controls.

\section{DISCUSSION}

The fluid within the fetal alveolus appears to occupy the space which will be filled with air after birth. The TBF which flows normally from the fetal trachea is swallowed or added to the AF and provides a flushing mechanism whereby entry of foreign substances into the fetal airway is minimized. Even during normal fetal respiratory activity, which has now been well demonstrated, the exchange of TBF and AF appears to be minimal. This is dependent upon the short duration of inspiratory effort and the slow compliance of the fluid filled system $(12,28)$. Humphreys and associates and others have shown that TBF absorption ordinarily takes place very effectively via the pulmonary lymphatics after the onset of air breathing $(13,20,22)$.

Intrauterine asphyxia increases the rate and depth of fluid ventilation and the exchange of TBF with other substances surrounding the upper airway e.g., amnionic fluid, meconium, blood, etc., thus, introducing substances into the respiratory tract which are poorly absorbed and favor retention of fluid in the alveolus. Such substances also may cause direct toxic injury to the epithelium of the respiratory tract.

In the studies reported here, the mechanical exchange of fluid during lavage appears to have had some effect at the alveolar level because a larger fraction of maximal lung volume was retained at $5 \mathrm{~cm} \mathrm{H}_{2} \mathrm{O}$ distending pressure than in controls $(P<0.05)$. The cause for this is conjectural, but may be related to retention of air behind particulate matter blocking small airways because the retained volume at $5 \mathrm{~cm} \mathrm{H} \mathrm{H}_{2} \mathrm{O}$ pressure was higher in the $\mathrm{AF}+$ meconium lavaged animals (AF, 0.293; AF + meconium, 0.380). However, this may have been associated with stretching of the elastic components of the fetal lung, edema, or perhaps stimulation of the type II alveolar cell to secrete surface active material into the alveolar fluid, thus, permitting the formation of a more effective alveolar surface film $(9,16,27)$. Comparative cortisol concentrations (Table 1) do not indicate that fetal lavage was a stressful procedure. Both controls and lavaged animals have somewhat higher concentrations than reported by other investigators (5).

In the presence of amnionic fluid aspiration, it previously has not been determined whether the effect on pulmonary PC synthesis resulted from the aspiration of a toxic substance or from pulmonary ischemia with aspiration as a secondary event. Behrman et al. (6) have shown that pulmonary blood flow in the fetal monkey falls to near zero during intrauterine asphyxia. More recently, Farrell et al. (14) have demonstrated significant reductions in lung de novo synthesis of $\mathrm{PC}$ as indicated by reductions in $\left({ }^{14} \mathrm{C}\right)$ choline incorporation in monkeys made acidotic in vivo. However, these studies did not investigate whether AF aspiration was induced by the acidosis and whether pulmonary ischemia or a direct toxic effect of AF on the alveolar epithelium was responsible for the observed reduction in lung PC synthesis.

The reduction in lung $\mathrm{PC}$ specific activity for $\left({ }^{32} \mathrm{P}\right)$ orthophosphate after AF lavage indicates a significant compromise in de novo synthesis of PC as was demonstrated by Farrell et al. (13) in response to asphyxia. However, de novo synthesis in the lung has not been shown to be quantitatively important in SPC synthesis because the last enzyme in this pathway, choline phosphotransferase (EC 2.7.8.2), is not specific for saturated diglycerides and synthesizes predominantly $\mathrm{c}-1$ saturate, $\mathrm{c}-2$ unsaturate $\mathrm{PC}(31,32)$.

More recently, the deacylation-acylation enzymes (phospholipase $A_{2}$ [EC 3.1.1.4], co-enzyme $A$ dependent acyltransferase [EC 2.3.1.23], and lysophospholipase-acyltransferase) have been implicated in the rearrangement of $c-1$ saturate, $c-2$ unsaturate fatty acids on PC to synthesize fully saturated $P C(10,17,23,37)$. Thus, such a mechanism could incorporate $\left({ }^{14} \mathrm{C}\right)$ palmitate into SPC even though de novo synthesis was reduced as observed in the nonacidotic lavaged lambs (Fig. 2). Unpublished studies from our 
laboratory on fetal and adult sheep lungs have not demonstrated the presence of one of the acylation enzymes, lysophospholipase transacylase. This suggests that the co-enzyme A dependent acyltransferase (EC 2.3.1.23) is the acylation pathway in the lamb whereby palmitate is incorporated into SPC. Oldenborg and van Golde (33) have recently shown that this latter enzyme in the mouse lung increases in specific activity shortly before term and in response to betamethasone stimulation. However, other investigators have shown that the lung co-A dependent acyltransferase is nonspecific for saturated fatty acids and the product PC demonstrates a random esterification of unsaturated and saturated fatty acids $(17,18)$.

Under the experimental conditions in this study, two of the lavaged lambs became acidotic and we observed a reduction in $\left({ }^{14} \mathrm{C}\right)$ palmitate into SPC when compared to nonacidotic and acidotic control lambs (Fig. 2). These observations suggest that the acylation pathway in the lamb lung is compromised when AF lavage and acidosis occur together because neither acidosis nor lavage alone caused such reductions in $\left({ }^{14} \mathrm{C}\right)$ palmitate incorporation into SPC:

In conclusion, these observations indicate that fetal lung $\mathrm{PC}$ de novo synthesis is reduced by a toxic element in AF which is as yet unidentified. The toxic element appears to be unique to AF because $\mathrm{AF}$ and $\mathrm{AF}+$ meconium caused equally significant reduction in PC synthesis and there was no effect from TBF lavage. Additional data is presented which, although preliminary, suggest that acidosis, when it occurs concomitant with AF lavage, further compromises lung PC synthesis as evidenced by reductions in $\left({ }^{14} \mathrm{C}\right)$ palmitate incorporation. Because acidosis in the absence of AF lavage did not depress SPC specific activity, we speculate that $\mathrm{AF}$ aspiration and acidosis may be synergistic and contribute to the compromise of the pulmonary surfactant system in clinical syndromes of respiratory distress syndrome.

\section{REFERENCES AND NOTES}

1. Adams, F. and Fujiwara, T.: Surfactant in fetal lamb tracheal fluid. J. Pediatr., 63: 537 (1963)

2. Adams, F., Moss, A., Fagan, L. The tracheal fluid in the fetal lamb. Biol Neonate, 5: 151 (1963).

3. Adams, F., Nozaki, M., Chida, N., Salawy, A., and Norman, A.: Effects of hypoxemia, hypercarbia, acidosis and reduced pulmonary blood flow on the surfactant of the fetal lamb lung. J. Pediatr., 71: 396 (1967).

4. Adamson, T., Brodecky, V., Lambert, T., Maloney, J., Ritchie, B., and Walker, A.: Lung liquid production and composition in the in utero foetal lamb. Aust. J. Exptl. Biol. Med. Sci., 53: 65 (1975).

5. Alexander, D., Britton, H., Nixon, D., Ratcliffe, J., and Redstone, D.: Corticotrophin and cortisol concentration in the plasma of chronically catheterized sheep. Biol. Neonate, 23: 184 (1973).

6. Behrman, R., Lee, M., Peterson, E., Lannoy, C., Seeds, A.: Distribution of the circulation in the normal and asphyxiated fetal primate. Am. J. Obstet. Gynecol., 108: 956 (1970).

7. Brownlee, K.: In: Statistical Theory and Methodology in Science and Engineering. Chap 9, p. 297 (John Wiley and Sons, New York 1965).

8. Brumley, G., Chernick, V., Hodson, W. A., Normand. C., Fenner, H., and Avery, M.: Correlations of mechanical stability, morphology, pulmonary surfactant, and phospholipid content in the developing lamb lung. J. Clin. Invest., 46: 863 (1967).

9. Brumley, G. W., Knelson, J. H., Schomberg, D. W., and Crenshaw, C.: Whole and disaturated lung phosphatidylcholine in cortisol-treated, intrauterine growth retarded and twin control lambs at different gestational ages. Biol. Neonate, 31: 155 (1977).

10. Brumley, G., and van den Bosch, H.: Lysophospholipase-transacylase from rat lung: isolation and partial purification. J. Lipid Res., 18: 523 (1977).

11. Cruickshank, A.: Effects of the introduction of amniotic fluid into rabbit's lungs. J. Pathol. Bact., 61: 527 (1949).
12. Dawes, G., Fox, H., LeDuc, B., Liggins, G., and Richards, R.: Respiratory movements and rapid eye movement sheep in the foetal lamb. J. Physiol., 220: 119 (1972).

13. Eagan, E., Olver, R., Strang, L.: Changes in non-electrolyte permeability of alveoli and the absorption of lung liquid at the start of breathing in the lamb. J. Physiol., 244: 161 (19:5).

14. Farrell, P., Epstein, M., Fleischman, A., Oakes, G., and Chez. R.: Lung lecithin biosynthesis in the nonhuman primate fetus: determination of the primary pathway in vivo. Biol. Neonate, 29: 238 (1976).

15. Gikes, E., King, R., Mescher, E., Platzker, A., Kitterman, J., Ballard, P., Benson, B., Tooley, W., and Clements, J.: Radioimmunoassay of pulmonary surfaceactive material in the tracheal fluid of the fetal lamb. Am. Rev. Resp. Dis. 115: 587 (1977).

16. Grossman, G., and Robertson. B.: Lung expansion and the formation of the alveolar lining layer in the full-term newborn rabbit. Acta Paediatr. Scand. 64: 7 (1975).

17. Hallman, M., and Ravio, K.: Studies on the biosynthesis of disaturated lecithin of the lung: the importance of the lysolecithin pathway. Pediatr. Res., 8: 874 (1974).

18. Hasegawa-Sasaki, H. and Ohno, K.: Acyltransferase activities in rat lung microsomes. Biochem. Biophys. Acta., 380: 346 (1975).

19. Henderson, R. and Clayton, M.: Cryochromatography: a method for the separation of lung phosphoglycerides according to the number and length of saturated fatty acid components. Anal, Biochem., 70: 444 (1976).

20. Howatt, W., Avery, M., Humphreys, P., Normand, I., Reid, L., and Strang, L.: Factors affecting pulmonary surface properties in the foetal lamb. Clin. Sci., 29: 239 (1965).

21. Howatt, W., Humphreys, P., Normand, I., and Strang, L.: Ventilation of liquid by the fetal lamb during asphyxia. J. Appl. Physiol., 20: 496 (1965).

22. Humphreys, P., Norman, I., and Reynolds, E.: Pulmonary lymph flow and the uptake of liquid from the lungs of the lamb at the start of breathing. J. Physiol.. 193: 1 (1967).

23. Jobe, A.: The labelling and biological half-life of phosphatidylcholine in subcellular fractions of rabbit lung. Biochem. Biophys. Acta, 489: 440, 1977.

24. Johnson, J. W. C., Salem, E., Holzman, G. B.: Respiratory effects of added fluid. Am. J. Obstet. Gynecol., 89: 481 (1964)

25. Kikkawa, Y., Motoyama, E. and Cook, C.: The ultrastructure of the lungs of lambs. Am. J. Pathol., 47: 877 (1965).

26. Klein, A., and Becker, R. Surface tensions in lungs of hypoxic guinea pig fetuses aspirating amnionic fluid, Am. J. Obstet. Gynecol., II5: 842 (1973).

27. Krasno, J., Knelson, J., and Dalldorf, F.: Changes in the alveolar lining with onset of breathing. Am. J. Pathol., 66: 471 (1972).

28. Maloney, J., Adamson. T., Brodecky, V., Cranage, S., Lambert, T., and Ritchie. B.: Diaphragmatic activity and lung liquid flow in the unanesthetized fetal sheep. J. Appl. Physiol., 39: 423 (1975).

29. Martin, C., Murant, Y., Petrie, R., and Parer, J.: Respiratory movements in fetal rhesus monkeys. Am. J. Obstet. Gynecol., 119: 939 (1974).

30. Mattingly, D.: A simple fluorometric method for the estimation of free 11hydroxycorticoids in human plasma. J. Clin. Pathol. 15: 374 (1962).

31. Moriya, T., and Knoh, $\mathrm{H}$.: In vivo studies on the de novo synthesis of molecular species of rat lung lecithin. Tohoku J. Exp. Med. 112: 24I (1974).

32. Oldenborg, V., and van Golde, L.: Activity of choline phosphotransferase. lysolecithin-lysolecithin-acyltransferase, and lysolecithin acyltransferase in the developing mouse lung. Biochem. Biophys. Acta, 441 : 433 (1976).

33. Oldenborg. V., and van Golde, L.: The enzymes of phosphatidylcholine biosynthesis in the fetal mouse lung-effects of betamethasone. Biochem. Biophys. Acta, 489: 454 (1977).

34. Olver, R., and Strang, L.: Ion fluxes across the pulmonary epithelium and the secretion of lung liquid in the foetal lamb. J. Physiol., 241: 327 (1974).

35. Potter, E., and Bohlender, G.: Intrauterine respiration in relation to development of the fetal lung. Am. J. Obstet. Gynecol., 42: 14 (1941).

36. Scarpeli, E.: Fetal pulmonary fluid. Rev. Perinat. Med. 1: 49 (1975).

37. van Golde, L. M. G.: Metabolism of phospholipids in the lung. Am. Rev. Resp. Dis., 114: 977 (9176)

38. Whitehead, W. H., Windle, W. F., and Becker, R. F. Changes in lung structure during aspiration of amnionic fluid and during air breathing at birth. Anat. Rec., 83: 255 (1942).

39. The authors thank Lillian Blackmon, M.D. for a helpful review of this work.

40. This research was supported by the National Heart, Lung, and Blood Institute. grant HL-16442.

41. Requests for reprints should be addressed to: George W. Brumley, M.D., Box 3967, Duke Hospital, Durham, N. C. 27710 (USA).

42. Received for publication February 14, 1978.

43. Accepted for publication May 18, 1978. 